Ambiente \& Água - An Interdisciplinary Journal of Applied Science
ISSN 1980-993X - doi:10.4136/1980-993X
www.ambi-agua.net
E-mail: ambi-agua@agro.unitau.br

\title{
Exposure to occupational dust and changes in pulmonary function among cobblestone paving workers of Jimma, Ethiopia
}

\author{
doi: 10.4136/ambi-agua.1227
}

Received: 22 Oct 2013; Accepted: 08 Mar. 2014

\author{
Kalkidan Abate Hassen*; Mohammed Sadik Ibrahim \\ Jimma University (JU) - Jimma, Oromia Region, Ethiopia \\ College of Public Health and Medical Sciences \\ *Corresponding author: e-mail: kalkidan.hassen@ju.edu.et, \\ mohaisadik@yahoo.com
}

\begin{abstract}
The classic diseases of "dusty" occupations may be on decline, but they are not yet extinct. Studies have found associations between changes in ambient particulate air pollution and increased cardiorespiratory morbidity and mortality. A cross-sectional comparative study design was employed on 127 male nonsmoker cobblestone paving workers and 194 matched employed office workers as a reference in order to assess changes in pulmonary function related to dust exposure among cobblestone road paving workers of Jimma zone, Ethiopia. Data was collected using structured questionnaires and spirometric measurements after ethical clearance was obtained. Data was analyzed using unpaired t-tests to examine the differences between the groups. P-values equal or less than 0.05 were considered statistically significant; odds were calculated at a 95\% confidence interval. Cobblestone road paving workers had significantly higher odds of respiratory symptoms, dry cough $(\mathrm{p}<0.05)$, cough $(\mathrm{p}<0.01)$ and sore throat $(\mathrm{p}<0.001)$ compared to the reference. The FEV1 for workers exposed to cobblestone road paving workers ranged between $3.12-4.73 \mathrm{~L}$, with a mean of $3.96 \pm 0.6 \mathrm{~L}$, significantly lower than the reference groups who had a range of $3.3-4.78 \mathrm{~L}$ and a mean of $4.01 \pm 0.6 \mathrm{~L}(\mathrm{p}<0.05)$. The mean value of the ratio of FEV1/FVC was significantly decreased in the cobblestone road paving workers compared to the controls (87.2 (SD 4.3) v 89.5 (SD 5.4), $\mathrm{p}=0.01$ ). In conclusion, the study revealed clear evidence of the need for health education and for the promotion of activities directed towards mitigating respiratory hazards in order to foster a safe and healthy work environment.
\end{abstract}

Keywords: air pollution, dust exposure, particulate matter, pulmonary function.

\section{Exposição à poeira e alterações na função pulmonar entre trabalhadores de pavimentação com pedregulhos em Jimma, Etiópia}

\section{RESUMO}

As doenças clássicas associadas com trabalhos em ambientes empoeirados podem estar diminuindo, porém ainda não extintas. Estudos realizados associaram mudanças na poluição do ar em ambientes empoeirados com o aumento da morbidade e mortalidade cardiorrespiratória. Neste estudo comparativo transversal foram analisados 127 trabalhadores masculinos de pavimentação de estradas com pedregulhos, não fumantes e que foram 
comparados com 194 trabalhadores de escritório utilizados como referência para avaliar as alterações da função pulmonar relacionadas à exposição ao pó na zona de Jimma, Etiópia. Os dados foram coletados por meio de questionário estruturado após a autorização do Comitê de Ética e realizada a mensuração espirométrica. Os dados foram analisados utilizando-se o teste $\mathrm{t}$ não pareado para analisar a diferença entre os grupos. Valores de p igual ou menor que 0,05 foram considerados estatisticamente significativos e as razões de possibilidades foram calculadas com intervalo de confiança de $95 \%$. Trabalhadores de pavimentação de estrada tiveram uma razão de possibilidade significativamente maior de sintomas respiratórios, como tosse seca $(\mathrm{p}<0,05)$, tosse $(\mathrm{p}<0,01)$ e dor de garganta $(\mathrm{p}<0,001)$ em relação ao grupo de referência. O FEV1 para trabalhadores expostos ao trabalho de pavimentação de estrada variou entre 3,12 - 4,73 L com uma média de 3,96 $\pm 0,6 \mathrm{~L}$ significativamente menor do que os grupos de referência que apresentaram um intervalo de 3,3 - 4,78 L e média de 4,01 \pm 0,6 L $(\mathrm{p}<0,05)$. O valor médio da relação de FEV1/FVC foi significativamente menor para trabalhadores de pavimentação de estrada em comparação com o grupo de controle (87,2 (dp 4,3) contra 89,5 (dp 5,4); p = 0,01). Em conclusão, o estudo revelou evidências claras da necessidade de educação e promoção da saúde voltada para riscos respiratórios para promover um ambiente de trabalho seguro e saudável.

Palavras-chave: poluição do ar, exposição à poeira, partículas em suspensão, função pulmonar.

\section{INTRODUCTION}

The classic diseases of "dusty" occupations may be on the decline; but they are not yet extinct. According to the World Health Organization (WHO), almost one-third of the global disease burden can be attributed to environmental risk factors (Prüss-Üstün and Corvalán, 2006). WHO also has listed dust-producing operations that include sandblasting, rock drilling, stone cutting, sawing, chipping, grinding, polishing, breaking of sand molds, "shake-out", granule handling operations such as weighing and mixing and transferring dusty raw materials and products, which are typical of cobblestone paving work operations. Workers today still suffer from a variety of illnesses caused by dust they inhaled from the work environment, including acute and chronic respiratory functional impairment (WHO, 1999).

Cobblestone paving is a simple and replicable technology; its ability to create thousands of jobs is impressive. More than 20 towns in Ethiopia, including Addis Ababa, have now institutionalised cobblestone paving construction. A poor road network, expensive asphalt roads, declining economic activities, increased poverty and unemployment were some of the factors which influenced the city to find a road building technology that was labour-intensive, durable and easy to maintain (Ethiopia, 2011). However, like most road works, it presents respiratory occupational concerns which are worthy of study.

Many studies have found associations between daily changes in ambient particulate air pollution and increased cardiorespiratory hospital admissions, along with cardiorespiratory mortality (Nyberg and Pershagen, 2000). One approach to assessing the potential chronic effects of air pollution is to determine changes on lung functions by measuring volumes and determining lung capacities. Spirometry is the most common of all pulmonary function tests used to diagnose and monitor respiratory problems. Moreover, the measurement and monitoring of lung volume and capacity in order to rate occupational hazard is used to produce norms or policies related to preventive measure against occupational air pollutants (NIOSH, 2012).

According to a recent review of chronic obstructive pulmonary disease (COPD), $25 \%$ to $45 \%$ of patients diagnosed with the disease have never smoked, which makes occupational exposure as an attributing cause of COPD more likely (Salvi and Barnes, 2009). In developed countries, an estimated $15 \%$ of all COPD is attributable to occupational exposure (Hnizdo and 
Vallyathan, 2003). A Malaysian study has shown association of total dust exposure and respiratory symptoms such as cough, phlegm, chest tightness and also with lung function indices (Noor et al., 2000). Similarly, in panel studies, acute episodes of particulate air pollution have been associated with increased incidence of respiratory symptoms, and decreased lung functions (Pope et al., 1995).

In order to minimize occupation-related pulmonary risk of air pollution, prevention and continuous monitoring systems are necessary to provide norms for adequate personal respiratory protective measures for chronically exposed people. Thus, this study aimed to show existing changes in pulmonary function related to dust exposure, if any, and to generate evidence to integrate primary prevention methods towards dust-related mortality and morbidity.

\section{METHOD}

The study was conducted in Jimma town, located in the Oromia province of Ethiopia, $354 \mathrm{~km}$ South West of the capital Addis Ababa. The town has a temperature that ranges from 20-30 ${ }^{\circ} \mathrm{C}$ and with average annual rainfall of $800-2500 \mathrm{~mm}^{3}$. The town has an altitude of 1750-2000 m above sea level. A cross-sectional comparative study design was employed on 127 male nonsmoker cobblestone paving workers and 194 nonsmoker government-employed office workers as a reference. Sample size was calculated using OpenEpi info software assuming two-sided confidence level (1-alpha) of 95, a Power of 80, a ratio of Controls to Cases of two, a hypothetical proportion of controls with an exposure of 40, a hypothetical proportion of cases with exposure of 57.14 with least extreme Odds Ratio to be detected of 2.00 of non-response rate of $15 \%$. Data was collected using a structured questionnaire and spirometric measurement using lung function measurement was performed using a portable digital Spirometer (Vitalograph 2120), after ethical clearance was obtained from the review board of the College of Public Health and Medical Sciences, Jimma University, Ethiopia. Cobblestone paving workers were matched with the reference by confounding factors to increase the efficiency of statistical analysis. Age, sex, weight and height were used for matching. The reference subjects were randomly selected after the number of study subjects (cobblestone paving workers) was saturated. Subjects who take short-acting bronco dilators or had medically diagnosed pulmonary disease or who had been on an anti-Tuberculosis drug for the preceding six months, workers with any form of oral lesion or bleeding, subjects with an active upper respiratory infection and with chest deformities were excluded. Data was analyzed using unpaired t-tests to examine the difference between the groups. P-values equal or less than 0.05 were considered statistically significant. Odds were calculated at a $95 \%$ confidence interval).

\section{RESULTS}

\subsection{Socio-demographic characters}

Among 321 respondents, 194 were government-employed office workers and 127 were cobblestone paving workers. Respondents were comparable among the groups, with a mean (sd) age of 26.4 \pm 9 years for cobblestone and $27 \pm 5$ for the reference (Table1). The reference groups were more educated (grouped) compared to cobblestone paving workers ( $2 \pm 1.2$ vs. $3 \pm 1.4$, where primary, secondary and territory levels educations are assumed hierarchically). Similarly, the reference groups had worked more years at their current jobs than compared to the cobblestone workers ( $3.3 \pm 1.4$ vs. $7 \pm 3.9$ years). 
Table1. Comparisons of the study subjects and the reference population in Jimma, Ethiopia, 2013.

\begin{tabular}{l|ccc}
\hline \multicolumn{1}{c|}{ Variables } & $\begin{array}{c}\text { Cobblestone workers } \\
\mathrm{N}=127\end{array}$ & $\begin{array}{c}\text { Reference group } \\
\mathrm{N}=194\end{array}$ & P value \\
\hline Age & $26.4 \pm 9$ years & $27 \pm 5$ & 0.65 \\
Duration at current work & $3.3 \pm 1.4$ years & $7 \pm 3.9$ & $0.02 *$ \\
Weight & $59 \pm 9.6 \mathrm{~kg}$ & $61 \pm 7.7$ & 0.32 \\
height & $162 \pm 8.3 \mathrm{~kg}$ & $163 \pm 4.2$ & 0.53 \\
Educational status (grouped) & $2 \pm 1.2$ & $3 \pm 1.4$ & $0.01 *$ \\
\hline
\end{tabular}

*significant.

The study result showed (Table 2) that Cobblestone paving workers had a higher frequency and odds of respiratory symptoms. Having dry cough $(\mathrm{p}<0.05)$, Cough with sputum production $(\mathrm{OR}=4.957, \mathrm{p}<0.01)$ and sore throat $(\mathrm{OR}=5.842, \mathrm{p}<0.001)$ showed a significant statistical association compared to the reference. They also had a higher prevalence of dyspnea 9 (7\%), diagnosed lower respiratory infection $9(7 \%)$ and wheezing 8 (6.2\%), but were not statistically significant. Utilization of protective devices by cobblestone paving workers was $3.2 \%$. The most common reasons for not using protective devices were "dust of such kind don't harm" $65 \%$, "I don't have mask" $31 \%$, and "unmasking is better" $17 \%$.

Table 2. Occurrence and frequency of respiratory symptoms in last three months among cobblestone paving workers and references population in Jimma, Ethiopia, 2013.

\begin{tabular}{l|ccccc}
\hline \multicolumn{1}{c|}{$\begin{array}{c}\text { Respiratory } \\
\text { symptoms }\end{array}$} & $\begin{array}{c}\text { Cobblestone } \\
\text { workers } \\
\mathrm{n}=127\end{array}$ & $\begin{array}{c}\text { Reference } \\
\text { group } \\
\mathrm{n}=194\end{array}$ & OR & CI & P value \\
\hline Dry cough & $17(13.4 \%)$ & $11(5.6 \%)$ & 2.571 & $1.093-6.119$ & $0.028^{*}$ \\
dyspnea & $9(7 \%)$ & $10(5.2 \%)$ & 1.403 & $0.506-3.872$ & 0.634 \\
Cough with sputum & $12(9.4 \%)$ & $4(2 \%)$ & 4.957 & $1.439-18.689$ & $0.007^{*}$ \\
Sore throat & $17(13.4 \%)$ & $5(2.5 \%)$ & 5.842 & $1.956-18.660$ & $0.001^{*}$ \\
Chest wheezing & $8(6.2 \%)$ & $6(3.1 \%)$ & 1.890 & $0.578-6.309$ & 0.372 \\
Diagnosed LRTI** & $9(7 \%)$ & $7(3.6 \%)$ & 1.907 & $0.629-5.867$ & 0.316 \\
\hline
\end{tabular}

* Significant; **lower respiratory tract infection.

Spirometric measurement were recorded at ambient temperatures of $20-24^{\circ} \mathrm{C}$ and corrected to body temperature and pressure saturated with water vapor (BTPS). The mean (sd) of Forced Vital Capacity (FVC) of the cobblestone paving workers ranged between 3.7-5.1 L with a mean $4.4 \pm 0.5 \mathrm{~L}$ lower than the reference, who had a mean (sd) $4.5 \pm 0.6 \mathrm{~L}$, but not 
statistically significant (Table 3). The forced expiratory volume in one second (FEV1) of cobblestone paving workers ranged between $3.12-4.73 \mathrm{~L}$ with a mean of $3.96 \pm 0.6 \mathrm{~L}$, significantly lower than FEV1 of the reference subjects' FEV1, ranged 3.3-4.78 L and a mean of $4.01 \pm 0.6$.

Table 3. Comparisons of pulmonary volumes among cobblestone paving workers and references population in Jimma, Ethiopia, 2013.

\begin{tabular}{l|ccc}
\hline Pulmonary functions & $\begin{array}{c}\text { Cobblestone workers } \\
\text { Mean (sd) }\end{array}$ & $\begin{array}{c}\text { Reference group } \\
\text { Mean (sd) }\end{array}$ & P value \\
\hline FVC & $4.4(0.5)$ & $4.5(0.6)$ & 0.16 \\
FEV1 & $3.96(0.6)$ & $4.01(0.6)$ & $0.03^{*}$ \\
FEV1\% & $87.2(4.3)$ & $89.5(5.4)$ & $0.01^{*}$ \\
\hline
\end{tabular}

*Significant.

The mean value of the ratio of FEV1\% significantly decreased in the cobblestone paving workers compared to the reference $(87.2 \pm 4.3$ vs $89 . \pm 5.5, \mathrm{p}=0.01)$. There appeared to be no statistically significant differences in FVC between cobblestone paving workers and the reference, although cobblestone paving tended to have lower lung function parameters. On the contrary, FEV1 and FEV1\% showed a significant reduction (Tables 3 and 4) among cobblestone paving workers $(\mathrm{P}<0.05)$. Tests for association conducted by independent $\mathrm{t}$ test with $95 \%$ CI revealed that there is a significant association between the duration of work in years and the FEV1. The result showed reduced FEV1 among cobblestone paving workers with longer durations of work $(\mathrm{P}<0.001)$.

Table 4. Duration of exposure (adjusted) and lung function among cobblestone paving workers: In dependent sample t-test, Jimma, Ethiopia. 2013.

\begin{tabular}{c|cccc}
\hline Lung function & F-Statistics & T & $\begin{array}{c}\text { P-value } \\
\text { (Two tailed test) }\end{array}$ & $\begin{array}{c}\text { 95\% Confidence Interval of } \\
\text { the Difference }\end{array}$ \\
\hline FVC & 6.25 & 2.48 & $0.013^{*}$ & $(0.01-0.09)$ \\
FEV1 & 20.01 & 4.01 & $0.000^{*}$ & $(0.06-0.17)$ \\
FEV1\% & 19.19 & 4.32 & $0.000^{*}$ & $(1.57-4.42)$ \\
\hline
\end{tabular}

*Significant.

\section{DISCUSSION}

Classic epidemiological studies revealed chronic dust exposure among the major risk factors for chronic obstructive lung disease, while the recent clinical and pathological experimental studies have contributed further towards elucidating the pathophysiological mechanism by which dust can cause alteration that leads to the development of the disease (Hnizdo and Vallyathan, 2003). Cobblestone paving work involves stone crushing which continuously generates significant amount of dust in the atmosphere. The present study showed that the burden of air pollution is not evenly shared among the groups. Cobblestone paving workers were found to have more respiratory symptom and reduced lung volume. The socio-demographic comparisons of the study revealed that cobblestone paving workers were less educated than their matched (age, sex, height and weight) references. Many studies have 
explored such differences in engagement with occupational hazardous work among less educated groups; such phenomenon was included in a workshop of the American Lung Association held in 2001 that focused on air pollution and health inequities (American Lung Association, 2001). The same finding was observed in a study done by O'Neill et al. (2012) and a review of Laurent et al. (2007).

More respiratory symptoms were found among exposed cobblestone paving workers than among the reference and were consistent with the Groneberg et al. (2006) review, which showed an aggregate of evidence focused on occupational causes of respiratory symptoms, particularly cough, being one of the most prevalent work-related airway symptoms. Similarly, Faria et al. (2006) and Schenker et al. (2005) also showed more respiratory symptoms among workers exposed to higher dust concentrations.

The spirometric data of the current study showed a lower but not a significant reduction in FVC measurements relative to the reference groups. However, FVC alone can't justify absence of alteration in pulmonary function as FVC can be normal or slightly decreased in patients with obstructive lung conditions (Gildea and McCarthy, 2003). Considering short duration of work for exposed groups, the lower FVC value is still clinically important as change in pulmonary parameters are the product of multiple years of exposure. There is a statistically significant reduction in FEV1 consistent with studies done by Jenny et al. (1960) and Yang et al. (1996) among workers exposed to cement and construction dust which was indicative of altered airway patency.

FEV $1 \%$ is significantly reduced among cobblestone paving workers, which is similar to studies done by Al-Neaimi et al. (2001) and Mwaiselage et al. (2004). The results also showed a significant reduction in FEV1\%, which indicates an obstructive impairment which could be due to mechanical irritation caused by exposed dust and individual susceptibility. Generally, the pulmonary function tests are more decreased in cobblestone workers as compared to the reference. Such pulmonary volume changes suggest an urgent need to improve dust control measures and health awareness towards dust prevention measures.

The data for use of protective devices was too small (3.2\%), as was knowledge regarding protective devices among the cobblestone workers, which further justifies the need for health education on the prevention of occupational hazards and more specifically on respiratory ailments related to air pollution.

\section{CONCLUSION}

In conclusion, our study showed adequate evidence of the need for health education and other activity directed towards the reduction of respiratory hazards in order to foster a safe and healthy work environment, which will in turn maintain and promote workers' health, working capacity and productivity.

\section{ACKNOWLEDGEMENTS}

We thank Jimma University for funding the study.

\section{REFERENCES}

AL-NEAIMI, Y. I.; GOMES, J.; LLOYD, O. L. Respiratory illnesses and ventilatory function among workers at a cement factory in a rapidly developing country. Occupational Medicine, v. 51, n. 6, p. 367-373, 2001. http://dx.doi.org/10.1093/occmed/51.6.367 
AMERICAN LUNG ASSOCIATION. Urban air pollution and health inequities: a workshop report. Environmental Health Perspectives, v. 109, p. 357-374, 2001. Suppl 3.

ETHIOPIA. Road Transport Authority. Cobblestone road construction in Ethiopia. 2011. Available in: www.ethiocities.com. Access in: 08 Mar. 2014.

FARIA, N. M. X.; FACCHINI, L. A.; FASSE, A. G.; TOMASI, E. Farm work, dust exposure and respiratory symptoms among farmers. Revista de Saúde Pública, v. 40, n. 5, p. 827-836, 2006. http://dx.doi.org/10.1590/S0034-89102006005000006

GILDEA, T. R.; MCCARTHY, K. Pulmonary function tests. In: Cleveland Clinic. Center for Continuing Education. 2003. Available in: http://www. clevelandclinicmeded.com/medicalpubs/diseasemanagement/pulmonary/pulmonaryfunction-testing/. Access in: 8 Mar. 2014.

GRONEBERG, D. A.; NOWAK, D.; WUSSOW, A.; FISCHER, A. Chronic cough due to occupational factors. Journal of Occupational Medicine and Toxicology, v. 1, p. 3, 2006. http://dx.doi.org/10.1186/1745-6673-1-3

HNIZDO, E.; VALLYATHAN, V. Chronic obstructive pulmonary disease due to occupational exposure to silica dust: a review of epidemiological and pathological evidence. Occupational \& Environmental Medicine, v. 60, p. 237-243, 2003. http://dx.doi.org/10.1136/oem.60.4.237

JENNY, M.; BATTIG, K.; HORISBERGER, B.; HAVES, L.; GRANDJEAN, E. Industrial medicine investigation in cement factories. Schweizerische Medizinische Wochenschrift, v. 60, n. 25, p. 705-710, 1960.

LAURENT, O.; BARD, D.; FILLEUL, L.; SEGALA, C. Effect of socioeconomic status on the relationship between atmospheric pollution and mortality. Journal of Epidemiology and Community Health, v. 61, n. 8, p. 665-675, 2007. http://dx.doi.org/10.1136/jech.2006.053611

MWAiselaGE, J.; BRÅTVEIT, M.; MOEN, B.; MASHALlA, T. Cement dust exposure and ventilatory function impairment: an exposure-response study. Journal of Occupational and Environmental Medicine, v. 46, n. 7, p. 658-667, 2004.

NATIONAL INSTITUTE FOR OCCUPACIONAL SAFETY AND HEALTH - NIOSH (United States). Centers for Disease Control and Prevention. Spirometry quality assurance: common errors and their impact on test results. DHHS (NIOSH) Publication n. 2012-116. Available in: http://www.cdc.gov/niosh/docs/2012-116/. Access in: 08 Mar. 2014.

NOOR, H.; YAP, C. L.; ZOLKEPLI, O.; FARIDAH, M. Effect of exposure to dust on lung function of cement factory workers. Med J Malaysia, v. 55, p. 51-57, 2000.

NYBERG, F.; PERSHAGEN, G. Epidemiological studies on the health effects of ambient particulate air pollution. Scandinavian Journal of Work, Environment and Health, v. 26, p. 49-89, 2000. Suppl 1.

O'NEILL, M. S.; BELL, M. L.; RANJIT, N.; CIFUENTES, L. A.; LOOMIS, D.; GOUVEIA, N. et al. Air pollution and mortality in Latin America: the role of education. Epidemiology, v. 19, n. 6, p. 810-819, 2008. http://dx.doi.org/10.1097/ EDE.0b013e3181816528 
POPE, C. A.; BATES, D. V.; RAIZENNE, M. E. Health effects of particulate air pollution: time for reassessment? Environmental health perspectives, v. 103, n. 5, p. 472-480, 1995.

PRÜSS-ÜSTÜN, A.; CORVALÁN, C. Preventing disease through health environments. Towards an estimate of the environmental burden of disease. Geneva: WHO, 2006.

SALVI, S. S.; BARNES, P. J. Chronic obstructive pulmonary disease in non-smokers. The Lancet, v. 374, p. 733-743, 2009.

SCHENKER, M. B.; FARRAR, J. A.; MITCHELL, D. C.; GREEN, R. S.; SAMUELS, S. J.; LAWSON, R. J. et al. Agricultural dust exposure and respiratory symptoms among California farm operators. Journal of Occupational and Environmental Medicine, v. 47, n. 11, p. 1157-1166, 2005. http://dx.doi.org/ 10.1097/01.jom.0000181174.02282.0c

WORLD HEALTH ORGANIZATION - WHO. Hazard prevention and control in the work environment: Airborne dust. WHO, 1999. Available in: http://www.who.int/occupational_health/publications/airdust/en/. Access in: 08 Mar. 2014.

YANG, C. Y.; HUANG, C. C.; CHIU, H. F.; CHIU, J. F.; LAN, S. J.; KO, Y. C. Effects of occupational dust exposure on the respiratory health of Portland cement workers. Journal of Toxicology and Environmental Health, v. 49, p. 581-588, 1996. http://dx.doi.org/10.1080/009841096160637 